\title{
BRICS engagement for global governance: perspectives of the Chinese leadership
}

\author{
Simona Picciau*
}

\section{INTRODUCTION}

During the last years, China is placing an unprecedented emphasis on the BRICS. In 2013, the Eighteenth Congress of the Chinese Communist Party identified this group (together with the United Nations, G20 and Shanghai Cooperation Organization - SCO) as the main multilateral institutions in which China desires to invest its efforts in order to play an active role in international affairs. As the largest economy among the five countries and the second economic power in the world, China plays the role of a natural leader of the BRICS, since the group establishment.

China's perception of itself in the global system is seriously changing, especially since the 2008 financial crisis changed the mapping of the world economy, pushing the developed countries to a relative decline in their power. In some way there is a general feeling in China that the country is returning to a position of centrality in the global system.

Moreover, the strong Chinese engagement in the BRICS reflects its objective to be more and more integrated into the new global order and to pursue the objectives of its foreign policy. First, in China's perspective, the emerging powers deserve a louder voice on the global economic and political scene, and the pragmatic attitude of the BRICS is viewed as an instrument that will enable the realization of a more democratic global order. The New Development Bank (founded by BRICS), represents, for instance, an alternative to the traditional international institutions such as IMF and the World Bank, especially for the African and Latin American countries. Second, through its engagement in multilateral forums such as the BRICS, China aims at improving its image at the

\footnotetext{
* $\mathrm{PhD}$ in International Relations at Université Paris Diderot Sorbonne Cite', Visiting Scholar and lecturer at the Goethe University of Frankfurt.
} 
international level and presenting itself as a friendly, supportive and trustworthy partner, totally committed to the establishment of a more equal global order.

China perceives its prominent role in the BRICS as an opportunity to guarantee its national interests, especially with regards to its relations with the developing countries with their raw materials that are more and more necessary to support its growing economy. The inclusion of South Africa as a new member of the BRICS was strongly supported by China, given the strong geopolitical interests of China in the African continent.

In the first part of the article we will present an overview of the main objectives of the Chinese foreign policy, especially since the Xi Jinping era. Sequentially, these objectives will be viewed through the framework of the Chinese engagement in the BRICS in order to discuss the future of the group and its significance in the development of China as a global actor.

\section{THE CHINESE DREAM AND THE NEW GLOBAL STATUS}

China today is a giant in transition. The Chinese leadership faces the most difficult task probably since the Deng Xiaoping era: continue to drive the most populous nation of the world with its 1.3 billion people to the development path in the new global order context characterized by a transition of power and the emergence of the so-called multipolar world.

The challenges Beijing faces are ambitious but inevitable and they involve profound changes both internally and externally. China is at an inflection point and the current President Xi Jinping appears to realize that the country needs a change (SCHELL, 2013, p. 51). The success of this change is based on Xi Jinping's capacity to strike the right balance between, on the one hand, a sustainable internal growth and social stability, and on the other hand the affirmation of China as a global power. If for a long time the internal affairs have been separated from the foreign affairs, in a globalized system these two dimensions become interdependent and inseparable.

Sustainable internal growth in the next decades requires proper management of the social inequality that represents a danger to the harmony of the Chinese society. The differences in terms of economic and social development between the coast and the countryside are still very stark, resulting in approximately 300 million migrants leaving the countryside for the urban areas (KONIG, 2012). The benefits of the economic reforms promoted by Deng Xiaoping since the end of the 1970s have accrued disproportionality, benefiting the coastal provinces, by generating an increasing inequality in the income distribution. If, in the mid-1990s, China was considered one of the most equal societies in the world; today its national Gini coefficient exceeds 0.45 (ASH; PORTER; SUMMERS, 2012, p. 28). 
The problem of the inequalities in Chinese society resulting from the rapid economic boom has been taken into account during the 2000s. In particular, between 2003 and 2005 the concept of harmonious society acquired centrality in the discussion under the leadership of $\mathrm{Hu}$ Jintao and considered an essential element to avoid social tensions and disorder. The 12th five-year plan, for 20112015, approved by the Chinese Communist Party, in March 2011, declared that in the future one of the main objectives of the government is to guarantee domestic coherence and achieve qualitative enhancement of the people's lives. The Party is well aware that the domestic socioeconomic inequality represents a threat to internal stability, an essential element during transition. In this situation, strengthening the sense of the national sentiment of the people, that they belong to a great civilization, through the use of rhetoric and propaganda slogans is used by the government to maintain the unity of the society. The anti-corruption campaign that has been launched by $\mathrm{Xi}$ Jinping is an example of a strong and visible measure taken by the government in order to restore the people's sense of trust in the central and local governments.

From a strictly economic point of view, China's economy has transitioned over the past few decades from a planned economy into a market economy at enormous social costs. According to a study conducted by the WHO and a group of universities, pollution alone has contributed to 1.2 million premature deaths in the country. Over $70 \%$ of the Chinese lakes are polluted and nearly one-quarter of Chinese do not have access to drinking water. The excessive use of toxic chemicals in industrialization has produced 400 cancer villages, in which the rate of cancers is higher than the normal rate. Today the Chinese government needs to complete its transition from an essentially export-based economy to an economy based on domestic consumption and innovation and the social costs involved can no longer be ignored.

With the concept of the Chinese Dream Xi Jinping wants to achieve a great national revival and emphasize the sense of unity in the nation under the party leadership and through the essential elements of Chinese culture and the reappropriation of its identity and values essential to building a new socialist morality, blending the socialist principles with the humanistic spirit of Confucianism (SCARPARI, 2015, p. 9). In recent years, public anger and protests have increased, representing a menace for the stability and harmony of society. In this context the party wants to maintain its legitimacy assuring the people that it is working hard to guarantee social stability and an international environment favourable to the development of Chinese society. During the $18^{\text {th }}$ National People's Congress in Beijing, Xi affirmed: "The Chinese Dream, after all, is the dream of the people. We must realize it by closely depending on the people. We must incessantly bring benefits for the people" (ZHAO, 2013).

The core concept of the Chinese Dream is one of rejuvenation of the nation (WANG, 2013, pp. 1-13) considered the main objective of Xi's government. This means the return of China to its natural state of glory. The recent ascension of 
China in the international system has reinforced confidence in the Chinese government that the country is returning to a position of 'centrality' in the global system, especially after the financial crisis of 2008 which changed the map of the world economy, pushing the developed countries to a relative decline in their power. The Chinese Dream can be considered a broad concept including the rejuvenation (fuxing) of the Chinese society in terms of domestic development but at the same time the return to the global stage as a great power.

With the concept of the Chinese Dream Xi appears to want overcome the dichotomy between domestic and external affairs, typical of the Deng Xiaoping's era. On the one hand, the engagement of China in global leadership is necessary to assure its internal stability and security. As Yang Jiechi, State Councillor and former Minister of Foreign Affairs of the People's Republic of China stated in the document Innovations in China's Diplomatic Theory and Practice under New Conditions: "The Chinese Dream requires a peaceful and stable international and neighbouring environment, and China is committed to realizing the dream through peaceful development. As the Chinese Dream is closely linked with the dreams of other peoples around the world, China is committed to helping other countries, developing countries and neighbouring countries in particular, with their development while achieving development of its own. China will share more development opportunities with other countries so as to facilitate their efforts to realize their dreams. China hopes to see win-win cooperation and common development with the rest of the world. While working to realize the Chinese Dream, the people of China are desirous of realizing the world dream through concerted efforts with people around the world (YANG, 2013). On the other hand, China cannot become a recognized great power if its international rise is not accompanied by economic development and social improvement. As suggested by Yanzhong Huang: "the profound sociopolitical problems are threatening China's great achievements. Until China can address the immeasurable, if not irreversible, social costs of development, it would be next to impossible for the nation to take a leadership role in the international system" (ZHONG, 2013).

It is important to note that while in the western world people refer to the Chinese rise, from the Chinese perspective it is not at all a rise from nothing but a genuine return to all its grandeur after a century of national humiliation that began with the First Opium War between 1839 and 1842 and lasted until 1945 with the culmination of the Sino-Japanese War in 1945.

The Eurocentric approach to interpreting history often ignores the dominant role played by China between 1100 and 1800. To cite some examples: Since 1078, China was the first producer of steel with an output of 125,000 tons; whereas, in 1788 Great Britain produced 76,000 tons. Before the English textile revolution in the XVIII century, China was the world leader in the textile-manufacturing sector in terms of technical innovations. Until the XIX century China had the largest commercial navy in the world; it was the leader in innovation in the fields of production of paper, stamped books, weapons and 
other manufactured products distributed around the world through its advanced navigation system (PETRAS, 2012).

Considering Chinese history alone, it played a central role in global affairs for centuries and its decadence began since the arrival of the European nations into its territory; therefore, it is possible to understand what the Chinese Dream concept really means.

While in China the debate regarding foreign policy is divided between the defensive internationalists, according to which China needs to play a role in the existing institutions of global governance pushing on prudence and the nationalists who want China to assert itself on the global stage (LEONARD, 2012, p. 11), the Chinese government has created a new doctrine of development. This is slowly overtaking and replacing the Hide capabilities and keep a low profile concept (Tao guang yang hui) instituted in the early 1990s by Deng Xiaoping, with the new one, Striving for achievement (Fen fa you wei), supported by many Chinese scholars in the country.

Wang Yizhou, Deputy Director, Institute of World Economics and Politics in the Chinese Academy of Social Sciences ${ }^{1}$ has theorized the concept of Creative Involvement according to which China must play a more active role and voluntarily involve itself in international affairs. But unlike the United States, Creative Involvement does not imply interference; rather, it takes into account acceptance by other countries and China's own strength (WANG, 2013).

Wang Yizhou's concept appears more and more in line with the doctrine of Striving for achievement. According to Xi Jinping, China has to steadily grow in confidence regarding its role in international development and play a part in shaping this development in a multipolar world (duoji shijie), a concept introduced in 1992 by the President and Chairman of the Central Military Commission, Jiang Zemin, during the $14^{\text {th }}$ Congress of the Communist party in China. For this reason the country can no longer assume a low profile but should take an active role in global affairs. For the Chinese this means, first of all, to present the state as a friendly and trustworthy partner; therefore, the nation wants to reassure the rest of the world that its ascension is pacific and that it does not constitute a threat to its partners (NIU, 2013).

Since the 1990s, its rising power has been perceived as a threat especially for the commercial concerns, as well as its investments in the military sector. Its authoritarian political system has generated, in the west particularly, a negative reputation of the country. In order to alleviate all of these suspicions, the theory of peaceful ascension, created in the recent years by the Chinese government, argues that the Chinese rise is beneficial both for China and the entire world population. Through its engagement in multilateral enterprises, Beijing desires to demonstrate its cooperative attitude and its engagement to rebalance the distribution of global power, giving a louder voice to the emerging powers, through, for example, reforms in the existing international institutions, like the International Monetary 
Fund (IMF), in particular, in the matters that concern the shifting of the vote power and by the creation of new multilateral platforms, engaging the emergence powers, such as the BRICS.

China wishes to become more engaged and present Chinese solutions, diplomatic concepts, shape the international system and be treated on an equal footing. However, there is a common consensus by scholars that China wants to pursue this objective by accepting the existing international rules and institutions. According to Zhengxu Wang, this appears to be one major element of China's grand strategy, rising into the existing world system instead of unsettling it (ZHENGXU, 2013).

China is also introducing economic diplomacy which involves the use of economic incentives to promote positive relations with the emerging powers, especially in the African countries; however, since the last decade this phenomenon has started to include the Latin American countries as well. Economic diplomacy is based on the principle of non-interference in the internal affairs of the country receiving economic assistance, which clearly desires to detach itself from the conditionality in assistance provided by the western international financial institutions, recognized as the Washington Consensus.

Another important component of the Chinese strategy to promote its image internationally is the use soft power, exerted particularly through the promotion of academic exchange, mandarin, its culture, its cinematography industry and setting up of the Confucius Institutes around the world with the specific objective of becoming a powerful instrument of Chinese cultural diplomacy.

\section{CHINA AND THE BRICS: SHAPING A NEW GLOBAL ORDER?}

The participation of China in the BRICS appears to be especially significant for Beijing because it is about a new multilateral platform, which draws together five emerging powers, each of which has an important role as a regional power, that China has contributed towards creating and in which it is playing a leadership role.

Its participation in the group is considered an important step towards realizing its foreign policy objectives. In 2013, the Eighteenth Congress of the Chinese Communist Party identified the BRICS, together with the United Nations, G20 and SCO, as the main multilateral institutions in which China wants to invest its efforts in order to play an active role in a multipolar world. The main reason for this attachment to the BRICS can be attributed to the limited number of multilateral forums similar to this, in which the emerging powers have the opportunity to strengthen their power and discuss their inclusion in global affairs.

After the economic crisis commenced in 2008, followed by the current transition from a unipolar world to a multipolar one, in 2009 the first BRICS Summit was held in Yekaterinburg (Russia), in which the four members of that 
period (South Africa joined the group in 2011) demanded "a greater voice and representation in international financial institutions" and "a more democratic and just multipolar world". Thus, BRICS appears to be an expression of what can be defined the rise of the rest, which includes not only the emerging powers and a series of non-state actors that are assuming an important role in the global affairs, but also new forms of cooperation in which the emerging powers play a central role like the SCO and others in which certain emerging powers have been admitted to the global forum of the main powers, as is the case of G20, in which BRICS members participate.

Due to the important role China assumed in the global economy, it appeared to be the natural leader since the time the group was formed. While this leadership generated admiration, there was at the same time a sense of fear that its leadership could transform into a type of domination. Its dominant position in terms of economic size compared with the other members induced a natural mixed feeling of both opportunity and fear. On one hand the economies of Brazil, India, Russia and South Africa are becoming more and more dependent upon Beijing, as the bilateral trade between China and the other four members of BRICS account for $85 \%$ of the total BRICS trade. At the same time its partners suffer from strong competition because of the low prices of the Chinese manufactured goods. It is true that if China wants to consolidate its role as leader it must consider all these elements. China has to very carefully apply its principle of pacific ascension within the BRICS framework, which, despite a solid purpose of strong cooperation, is characterized by divisions and rivalries, in particular with China, and there are substantial differences in the issues that concern their political systems, cultures and values. As suggested by Minghao Zhao: "BRICS represents a force multiplier for Beijing and can remain so if China is careful not to push its national interests too hard." (MINGHAO, 2015). The balance between its own interests and an altruistic attitude solidly aimed at establishing equal cooperation between its partners is, at this stage, vitally important.

\section{THE CREATION OF NEW MULTILATERAL FINANCIAL INSTITUTIONS: NDA AND CRA}

Over the recent years, China's engagement in financial multilateralism has accelerated, demonstrating its concrete commitment and determination in contributing to reforming the multilateral international financial system. The establishment of the New Development Bank (NDB), created in order to mobilize resources for the infrastructures and sustainable development projects in the emerging and developing countries, represents a new chapter in the relationship among the members, as it raised the level of cooperation from that of a lobby group to that of a more organized entity, capable of delivering solutions (CONTIPELLI, PICCIAU, 2015, pp. 82-93). 
The choice of establishing the New Development Bank's headquarters in Shanghai, after a long negotiation period, does not appear to be left to chance. China hopes that the bank's presence in Shanghai will boost the city's ambitions to become a financial center by 2020 . The new financial institution represents the concrete result of this cooperation and the resolution of the five members to play a central role in global cooperation. The NDB will kick start its operations with $\$ 100$ billion as the initial capital and the five countries will have equal voting shares.

The BRICS Contingency Reserve Arrangement (CRA) has been created in order to provide safeguards for the members and other countries in the context of considerable volatility of the existing financial. The new mechanism will provide liquidity to countries with difficulties in their balance of payment. China participates with $\$ 41$ billion, Russia, India and Brazil with $\$ 18$ billion each and South Africa with $\$ 5$ billion.

During the inauguration of the NDB on July 2015 in Shanghai, with representatives of all the founding members, the Chinese finance minister, Lou Jiwei together with the NDB's President, K. V. Kamath, former Chief Executive of the ICICI bank, India's largest private sector bank, avoided criticizing the existing international financial institutions and presenting the NDB as challenging the existing norms (WILDAU, 2015). This confirms the assumption presented in the first part of the article, that China's objective is not to change the international norms but to improve and make them more fair and favourable to creating a global order tilted towards China's development and its growing international influence. Of course, the new financial institution does represent an alternative to the international financial institutions such as the IMF and World Bank, reflecting the global order established after World War II, that is no longer consistent with the economic global power distribution, especially in the aspects that concern voting rights.

Through the participation in the creation and implementation of the $\mathrm{NDB}$ and the active role it plays within the institution, China realizes one its objectives, to become more attractive to the developing countries and build closer relations with them. To this purpose, Low Jiwei affirmed: "This bank will place greater emphasis on the needs of developing countries, have greater respect for developing countries' national situations, and more fully embody the values of developing countries" (WILDAU, 2015).

During the $7^{\text {th }}$ Summit held in Ufa (Russia) on 9 July, 2015 in the presence of Xi Jinping, Vladimir Putin, Dilma Roussef, Narendra Modi and Jacob Zuma, the New Development Bank and the Contingent Reserves Arrangement officially became operational. The five leaders underlined the nature of the NDB as an instrument for financing infrastructure and investment projects in the BRICS and other developing countries, and for enhancing cooperation between the BRICS members and CRA as an important step in the financial cooperation of the members. 
Creation of financial institutions appears to be one of the main methods employed by China to serve its economic and political agenda. Only one month prior to the inauguration of the NDB, China and 49 countries signed the Articles of Agreements (AOA) of the Asian Infrastructure Investment Bank (AIIB), with the objective of funding projects in the developing countries chiefly in Asia. In the first stage, China planned to extend the membership only to the Asian countries, and the fact that many non-Asian countries, beginning with the UK, applied to join it probably left China quite surprised. Many European, African and Latin American countries are now Founding Members (PFMs) and the capital share distribution is $75 \%$ to $25 \%$ for the regional members and non-regional members accordingly. The development bank aims to improve the connectivity of the Asian region which is a key component of China's Asian strategy, especially since Xi Jinping's arrival to power. As suggested by Zheng Yongnian, China must establish strong relations with the developed and developing countries, but prioritize its relations with its neighbours because the greater power needs the support of its neighbouring countries in order to rise (GODEMENT, 2015, p. 4).

With its engagement in the creation of these three financial arrangement, China is realizing its objectives: the creation of new multilateral institutions that will contribute to shape a new global order.

\section{STRENGTHEN THE RELATIONS WITH EMERGING COUNTRIES THROUGH BRICS}

China's engagement in BRICS represents an important framework through which the country can strengthen its relations with the emerging and developing countries and present itself as engaged in defending the rights of these countries.

The Chinese President Hu Jintao presents the group as the defender and promoter of the interests of all the developing countries through reinforcement of the South-South cooperation and the promotion of the North-South dialog. In others word, the BRICS group has started to be presented as fundamental to the on-going economic globalization and the democratization of the international relations, through a fairer distribution of the global world public goods and inclusion of emerging powers (THE INDU, 2012).

Strategically speaking, the creation of this new informal group has, of course, since its formation represented for China an important occasion to reinforce its bilateral relations with Brazil, India and Russia, all of who were defined strategic partners.

Concerning South Africa, in particular, its formal admission into the group during the third BRICS Summit that occurred on 14/15 April 2011 in Hainan (China), undoubtedly represented an important success of the President 
Zuma's foreign policy, strongly supported by Hu Jintao of China. According to Naidu this invitation enabled Beijing to demonstrate the growing role of China as a global leader, especially with regard to the South and developing world, reflecting its willingness to be engaged with the third world (LI, 2013).

In August 2010, when China and South Africa signed the Beijing Declaration, the two countries expressed their desire to further strengthen and deepen their cooperation in both political and regional affairs by establishing a comprehensive strategic partnership based on equality, mutual benefit and common development, the first that China signed with an emerging country. Since the first China-Africa Forum which took place in 2000, China imposed its presence in the African continent. The relations between China and Africa are ancient and borne mainly on ideological bases during the ' 50 s and '60s, and the symbol of this relation is probably constituted by the Tanzania-Zambia railway, built between 1969 and 1975 and financed by China under Mao, despite the fact that the country was experiencing a troubled period, post the Cultural Revolution.

Due to the natural resources and diplomatic sustenance of the African countries, the continent is becoming more and more a strategic stake for the emerging countries, especially for the other BRICS members. But, if the Brazilian and Indian presence in Africa is often considered by the local communities as beneficial for their territories because of their use of the local workforce and the transfer the technology to the local people, contributing to the general development of the African countries (BOKILO, 2011, p. 84), on the contrary, the Chinese presence often sparked protests because it was considered mainly advantageous for the Chinese companies alone. The use of the Chinese workforce in its infrastructure investment projects (mainly in the Democratic Republic of Congo, Angola, Zambia, Nigeria, Gabon and Mauritania) is considered a limitation for the development of the local communities, negatively affecting the image of China, accused of pursuing a neo-colonialist strategy in Africa. Of course, the Chinese interests in the African continent cannot be excluded from a general consideration of the reasons for the strong support offered by Hu Jintao to the entry of South Africa into BRIC. If its attention to the emerging powers and their inclusion in the global affairs is part of its soft strategy, it is true that Africa represents an important continent for the development of the Asian dragon. The inclusion of South Africa into BRIC was inspected and left the observers surprised, considering the comparatively smaller weight of the African country. According to some scholars it is difficult to perceive immediately how South Africa could fit into the group (WOOLDRIDGE, 2011). Undoubtedly its participation symbolizes the BRICS opening to the entire continent with a population of over one million people. Furthermore, for decades Africa was a "forgotten continent" for the western countries and its admission to this new platform of international cooperation demonstrated, for China, its willingness to be the nation leading on the inclusion of the emerging powers into the global system and contributing to the democratization of the international relations. But of course, South Africa 
admission into BRIC represents a good opportunity for China to guarantee its national interest on the continent, and specifically, its main objective to assure the energy resources necessary to sustain the economic growth of the country. In 2013, China imported 1.3 million barrels of oil per day from Africa (23\% of the total), while Chinese investments in Africa exceeded US $\$ 25$ billion. It is estimated that imported energy resources would account for $26 \%$ of the energy consumed in China in 2020, and would drop back down to around $15 \%$ in the following years (XU, 2014). Among China's major companies, ZTE and Huawei are establishing their African Headquarters in South Africa, and Beijing decided to locate the African headquarters of the China-Africa Development Fund in Johannesburg (BESADA; TOK; WINTERS, 2013, p. 5).

After Africa, South America appears to be a very important region for China, especially since the leadership of Hu Jintao. Since 2013, Xi Jinping paid two official visits to the region and created the China-CELAC Forum (Community of Latin American and Carribean States) in 2015 during which Xi Jinping announced an investment of $\$ 250$ billion in Latin America over the next decade. Despite Brazil presenting itself as the natural leader of the region, China has already become a major partner for the countries in this region and is trying to enhance its influence through BRICS. For example the $6^{\text {th }}$ BRICS Summit held in Fortaleza in 2014, was the occasion for the organization of the BRICS-South America Summit, (an initiative of the Brazilian government), with the presence, amongst others, of Nicolas Maduro (Venezuela), Evo Morales (Bolivia), Michelle Bachelet (Chile), Rafael Correa (Ecuador) and Cristina Fernandez Kirchner (Argentina). China is strongly intensifying its presence in South America because it is rich in natural resources and has a growing middle-class with a rising purchasing power. China is building its relationships based on receiving natural resources in exchange for loans necessary for the development of the South American region and improvement of the regional infrastructure system.

\section{BRICS AND INTERNAL STABILITY}

China is on the path towards the realization of its Chinese Dream. To actually realize it, the government needs a national unity and national consensus for both domestic and foreign policies. The national cohesion and stability are both the objectives and prerequisites for achieving the development of the country. The Chinese government will need to face serious changes in society in response to the demand of its growing population needs. The pride in the economic growth and its achievements in terms of national development are not sufficient to sustain the pact between the population and the Party. The population is profoundly affected by the social inequality and needs welfare in the areas of wealth, education, pension system, etc. The government will need to manage all these demands in a situation of economic recession. 
This is the reason that $\mathrm{Xi}$ Jinping is intensifying messages to the population regarding the fact that the government is taking care of its future and its prosperity together with a strong foreign policy that aims at creating a prosperous environment in which China can once again find its centrality.

A three-minute animated feature film titled "Briefing on Going with Uncle to SCO and BRICS" was published online in China. The video explains the significance of the BRICS and SCO summits (Shanghai Cooperation Organisation) and presented an overview of the member countries and their influences. The cartoon shows President Xi Jinping, called "Uncle" in a friendly tone, probably to present the idea of proximity between the President and the population, and the eight international leaders riding together on a single bicycle. The expressions in the cartoon are very interesting: "realizing flourishing mutual development is the goal", aimed at showing the unity among the members of the organizations. "Not like some people, always treating the world as their own personal property, making themselves the head of the household, rushing to others' doorways to show off their muscles at the slightest provocation", appears to be a clear reference to the United States and their unilateral manner of conducting international relations solely according to their own interests as against the "multilateral" actions by China and the other members of the BRICS. Another interesting aspect of the cartoon is that it depicts the friendly relationship between China and Russia. The carton shows Presidents Vladimir Putin and Xi Jinping walking together i with a caption that states: "China-Russia relations have been very warm recently", "Some people support it; others throw bricks. Attitudes are different because mentalities are different. Cold War thinking is already out" (RAMZY, 2015).

It is interesting to note that concerning Russia, just prior to Xi's Moscow visit in May (to celebrate the $70^{\text {th }}$ anniversary of the end of World War II), a video expressing the Chinese citizens' thoughts on Russia was distributed in China.

After this video on BRICS and SCO, another one was circulated in the Chinese social media by central television, concerning the new Five-Year Plan (2016-2020) that the Communist Party was going to discuss from 26 to 29 October, 2015. There are two versions of the same video, one in English, catering to the foreigners, and the other in Chinese. The video uses a few expressions like: "It's a huge deal/Like how huge?/Like China huge?/Yeah, China huge./Wow, that's really big?" This was clearly done to reveal that the government is initiating a great economic plan commensurate to the greatness of the Chinese nation.

\section{WHAT IS THE FUTURE OF BRICS?}

The role of BRICS in global governance is now facing greater challenges than ever before. The slowing economic growth in the BRICS countries could raise a debate on their credibility as a group in ascension. Though the cooperation has been expanding to include other policy areas like security for example, the 
group should retain its focus on economic cooperation among them and with the other emerging powers.

As the largest economy among the five countries, China's vision and strategy regarding the future of the BRICS group becomes increasingly important. If China wants to upgrade its international status, trying to translate its economic power into international influence, and consider its role of 'leader' within the group, it has to promote a broader cooperation amongst the BRICS members, in order to transform BRICS from an economic concept to a geopolitical one (NIU, 2015).

It is true that if China wants to affirm itself as a "Big Power" it must show its capacity in offering ideas and solutions to the conflicts and crises and contribute towards the achievement of globally relevant objectives through single initiatives and within the framework of its participation to multilateral institutions. Its serious engagement on the reduction of gas emission and fighting against climate change appears particularly significant.

As suggested by the Nobel Prize winner, Muhammad Yunus, economist and social entrepreneur, to be effective the New Development Bank should be green, and focus on poverty eradication. According to him, the New Development Bank, should be able to achieve three 'zeros' by 2050: zero poverty, zero unemployment and zero net carbon emission through four basic strategies. First, BRICS should mobilize the power of the youth. Second, the strategy should be focused on technological innovations to solve human problems. Third, they should be able to encourage social business, through the creation of country-level social business funds as joint ventures with local partners, in order to resolve long-standing and complex social, economic and environmental problems that conventional businesses cannot solve. Fourth, human rights and good governance should be at the heart of the NDB (YUNUS, 2015).

China's ability to encourage and contribute concretely to seek solutions to these dramatic questions that are solely the result of the human irresponsibility and mismanagement of public affairs both at national and international levels, within the framework of its participation to multilateral institutions, existenting or new ones, will mean that it will be able to assume the responsibilities that accompany its status of a rising power; even more so, considering its dimension and population size, with its 1.3 billion people representing $20 \%$ of the world population. If we consider that one out of every five people on the world is a resident of China, it is easy to understand the importance and necessity of China's engagement and responsibility in world affairs both for the wellbeing of the Chinese population as well as for the whole of humanity.

Its engagement in the group appears to be of fundamental importance for China's interests, not only because it aims at shaping global order through the democratization of the international relations but also for the expansion of its own global interests. China needs its BRICS partners to guarantee peace and stability in their regions, which are crucial to sustain its own growth. Russia, for 
example, is also a member of the Shanghai Cooperation Organization and the stability of the Central Asia, and cooperation with Russia are fundamental to the realization of the One Belt One Road project. Brazil, despite the on-going economic, political and social crises remains the major economy of the region and an important soybean supplier to China.

It is easily conceivable that if BRICS will not affirm itself as a geopolitical entity, this will negatively affect China's international image. This will depend on several factors - first on the members capacity to face their economic crisis and control the social dysfunctions, in an economy that appears more and more unstable. It appears that China, Brazil, Russia, India and South Africa will find it difficult to maintain the economic growth rate that they registered over the past. And second, their capacity to put their common interests and global interests at the core of their existence and resolve the internal rivalry within the group (CONTIPELLI; PICCIAU, 2015).

\section{CONCLUSIONS}

Chinese leadership today, faces enormous challenges that involve profound changes, both internally and externally. Xi Jinping needs to strike the right balance between a sustainable internal growth and social stability on the one hand and the affirmation of China as a global power on the other. The national rejuvenation and the pursuit of a "central" position as a global actor, under the concept of the Chinese Dream, appear to be the chief aim of Chinese development.

The foreign policy strategic objective is to realize the Chinese Dream, especially with the concept of Striving for achievement (Fen fa you wei) that involves a more active and voluntary role in international affairs.

One of the concrete examples is that China wishes to be involved in global affairs and shape the global system through its participation in the BRICS group, which was identified by the Eighteenth Congress of the PCC, as one of the main multilateral avenues, in which China wants to invest its efforts to play an active role in a multipolar world (with the United Nations, G20 and SCO).

Its engagement in BRICS represents, for China, an important opportunity to achieve its foreign policy goals, on a new multilateral platform, bringing together the emerging powers and contributing to the reinforcement of the South-South cooperation and the promotion of the North-South dialogue, in which China plays the leading role. Since its establishment, China presented itself in the group as the defender and promoter of the interests of all emerging countries through, for example, the creation of the new financial institutions, (NDA and CRA) that will provide economic and financial support to the BRICS members, as well as the developing and less developed countries. 
Furthermore, China's engagement in BRICS appears of fundamental importance as its interest is focused not only on shaping the world order through the democratization of the international relations but also on the expansion of its global and economic interests, in particular, securing natural resources for domestic development and new markets essential for its manufactured products.

As the largest economy among the five member countries, China's vision and strategy regarding the future of BRICS appear very significant, and the group needs to improve its capacity to be an active actor in the resolution of the global issues (climate change, poverty eradication, security, conflicts resolutions and others) moving from an economic forum of cooperation to a geopolitical entity.

China can be the leader of the group and demonstrate its ability to act on the the international stage. A hypothetical failure of the group could negatively affect China's image as a global power and in some way deface the Chinese Dream.

\section{NOTA}

1 Wang Yizhou is also vice Dean of the School of International Studies, Peking University.

\section{REFERENCES}

Ash, R., Porter, P., Summers, T. (2012), China, the EU and China's twelfth Five-year programme, Europe China Research and Advice Network, London 2012.

Besada, H., Tok, E, Winters, K. (2013), South Africa in the BRICS, Opportunities, Challenges and Prospects, Africa Insight. Vol 42(4)- March.

Bokilo, J., (2011), La Chine en Afrique. La Chine en concurrence avec les anciens partenaires de l'Afrique et les pays Brics, L'Harmattan, Paris.

Contipelli, E., Picciau, S., (2015), Institutional Status of BRICS and Pragmatic

Cooperation: The case of South America, International Organisations Research Journal, Special Issue: "BRICS in the System of Global Governance", vol. 10, n². P. 82/93.

Godement, F., (2015), Explaining China’s Foreign Policy Reset, European Council on Foreign Relations, p. 4.

Available at: http://www.ecfr.eu/page/-/ChinaAnalysisEng_Special_issue_1503_Final_ v3_(2).pdf.

Leonard, M., (2012), China 3.0., European Council on Foreign Relations (ECFR), Friedrich Ebert Stiftung, Fundacao Calouste Gulbenkian, Robert Bosch Stiftung.

Li Xing, Osman Farah, A., (2013), China-Africa Relations in an Era of Great Transformations, Ashagate. 
Minghao, Z., (2015), China's BRICS Balancing Act. 17 July. Available at: http://www. project-syndicate.org/commentary/brics-summit-china-leadership-by-minghaozhao-2015-07.

Niu Haibin, (2013), China's grand strategy and the BRICS. Contexto Internacional, vol. 35 no.1 Rio de Janeiro, Jan/June. Available at: http://www.scielo.br/scielo.php?pid=S010285292013000100007\&script=sci_arttext.

Niu Haibin, (2015), A Chinese Perspective on the BRICS in 2015, Council of Councils. 6 February. Available at http://www.cfr.org/councilofcouncils/global_memos/p36088.

O. Schell, (2013) Too Big to Quail. Xi Jinping takes over a nation beset by challenges and ready for change. Is China's new leader up to the job? In: Time, April 1.

Petras, J., (2012), Cina: ascesa, caduta e risalita come potenza mondiale, Geopolitica Rivista dell'Istituto di Alti Studi in Geopolitica e Scienze Ausiliare, 2012. Available at: http://www.geopolitica-rivista.org/16886/cina-ascesa-caduta-e-risalita-come-potenzamondiale.html.

Scarpari, M., (2015), Ritorno a Confucio. La Cina di oggi fra tradizione e mercato. Il Mulino.

Stiglitz, J., (2006), Global Public Goods and Global in Finance: Does Global Governance Ensure that the Global Public Interest is Served? In Advancing Public Goods. In Touffut, J.P., UK: Edward Elgar Publishing, p. 149.

The Indu, (2012), BRICS is the defender of the developing world, 28 march. Available at: http://www.thehindu.com/opinion/interview/brics-is-the-defender-of-the-developingworld/article3251562.ece.

Xiaojie Xu, (2014), La nuova strategia cinese in Africa, Affari internazionali, Rivista online di politica, strategia ed economia.

Ramzy, A., (2015), Xi Jinping of China Makes Cartoon Appearance Before Meeting in Russia. The New York Time, 7 July. Available at: http://sinosphere.blogs.nytimes. com/2015/07/07/xi-jinping-of-china-makes-cartoon-appearance-before-meetings-inrussia/?_r=0.SSN 2280-9228.

Konig, T., (2012), A guide to China's leadership changes. European Council on Foreign Relations. 29 October, 2012. Available at: http://www.ecfr.eu/article/commentary_a_ guide_to_chinas_leadership_changes.

Wang, Z., (2013), The Chinese Dream: Concept and Context, Journal of Chinese Political Science, 19(1), pp. 1-13.

Wang, Y., (2013), Creative Involvement: The Evolution of China's Global Role. Peking University Press.

Wildau, G., (2015), New Brics bank in Shanghai to challenge major institutions. FirstFT, 21 July. Available at: http://www.ft.com/intl/cms/s/0/d8e26216-2f8d-11e5-8873-

775ba7c2ea3d.html 
Wooldridge, M., (2011), Will BRICS strengthen South Africa's economic foundations? BBC News, [online] 5 January. Available a: t http://www.bbc.co.uk/news/ worldafrica-12113830.

Yang, J., (2013), Innovations in China's Diplomatic Theory and Practice Under New Conditions. Web site of the Ministry of Foreign Affairs of the People's Republic of China. Available at: http://www.fmprc.gov.cn/mfa_eng/wjdt_665385/zyjh_665391/t1066869. shtml.

YanZhong, H., (2013), The Dark Side of Growth, YaleGlobal, 6 June 2013. Available at: http://yaleglobal.yale.edu/content/china-dark-side-growth.

Yunus, M., (2015), The New Brics Bank Should be green and focus on poverty, The World Post, 7 July. Available at: http://www.huffingtonpost.com/muhammad-yunus/bricsdevelopment-bank-world-bank-mistakes_b_7756424.html.

Zhao, Y., (2013), Chinese'Dream in Xi' view. China Daily, available at http://www. chinadaily.com.cn/china/2013npc/2013-03/18/content_16315025.htm.

Zhengxu, W., (2013), China's incremental multilateralism: Toward a multi-polar world. The University of Nottingham. October 16. Availbla at: https://blogs.nottingham.ac.uk/ chinapolicyinstitute/2013/10/16/chinas-incremental-multilateralism-toward-a-multipolar-world/. 


\begin{abstract}
This article aims at analyzing the involvement of China in the BRICS as an instrument to achieve its foreign policies goals and the realization of the Chinese Dream proposed by the current President Xi Jinping. The Chinese Dream is a broad concept of a great national revival that emphasized the sense of unity of the nation and the return of the country to its natural state of glory under the communist party leadership. In the first part, we will present an overview of the main objectives of the Chinese foreign policy, particularly from Xi Jinping's era. Sequentially, these objectives will be discussed within the framework of the Chinese engagement in the BRICS to discuss the future of the group and its significance in the development of China as a global actor.
\end{abstract}

Keywords: China, BRICS, Multilateralism, Global Governance, New Global Order

RDUNO, v. 1, n. 1, Jan - Jul/2018 - pag (138-156) 


\section{Resumo}

O presente artigo tem como objetivo analisar o envolvimento de China nos BRICS, como instrumento para alcançar seus objetivos de política externa e a realização do "Chinese Dream" proposto pelo atual Presidente Xi Jinping. O "Chinese Dream” é um amplo conceito de renascimento nacional, que enfatiza o senso de unidade da nação e o retorno do país ao seu "estado natural de glória", sob a liderança do Partido Comunista. Na primeira parte, apresentaremos uma visão geral dos principais objetivos da política externa chinesa, particularmente, referente ao mandato de Xi Jinping. Posteriormente, esses objetivos serão discutidos no contexto do envolvimento chinês nos BRICS, para analisar o futuro do grupo e sua importância no desenvolvimento da China como um ator global.

Palavras-chave: China. BRICS. Governança global. Nova Ordem Global. 